\title{
Transgenic animal models for the functional analysis of vasoactive peptides
}

M. Bader

\author{
Correspondence \\ M. Bader \\ Max-Delbrück-Center for Molecular \\ Medicine (MDC) \\ Robert-Rössle-Strasse 10 \\ D-13122 Berlin-Buch \\ Germany \\ Fax: 49-30-9406-2110 \\ E-mail: mbader@mdc-berlin.de \\ Presented at the II International \\ Symposium on Vasoactive Peptides, \\ Ouro Preto, MG, Brasil, \\ October 6-8, 1997. \\ Research supported by the Deutsche \\ Forschungsgemeinschaft \\ (Ba1374/1,INK21/A1-1) and \\ Volkswagenstiftung (I/72741).
} .

Received January 6, 1998

Accepted January 26, 1998

$\ldots \ldots \ldots \ldots \ldots \ldots$
Max-Delbrück-Center for Molecular Medicine (MDC), Berlin-Buch, Germany

\section{Introduction}

Peptides such as angiotensins, kinins, endothelins, vasopressin and natriuretic peptides are the most important regulators in the cardiovascular system. They are liberated from larger precursor proteins by metabolizing enzymes and exert their actions by binding to receptors belonging to the class of heptahelical membrane proteins coupled to G-proteins (except the natriuretic-peptide receptors, which represent membrane-bound guanylate cyclases). These peptide systems were originally thought to act mainly in an endocrine manner since in most cases the precursor proteins and the processing enzymes are produced in distinct tissues and assemble in the circulation to produce the active peptides, which interact with receptors in cardiovascular target organs like heart, vessel wall, and kidney. However, in recent years the local production of peptides by precursors and enzymes jointly synthesized in several tissues has been detected and important regulatory functions have been ascribed to such tissue peptide systems. Especially in the case of short-lived peptides like kinins and endothelins this functioning mode seems to be more relevant than the endocrine action as much higher concentrations of the peptides can be reached at the receptor when they are produced in its immediate neighborhood. The functions of the locally produced peptides may be largely independent of the circulating systems especially at sites to which the circulating pep- 
tides have no access under normal circumstances, e.g., beyond the blood-brain and blood-testis barriers.

While the circulating peptide systems can be successfully studied using inhibitors of the processing enzymes or receptor antagonists, for the functional analysis of local peptide systems such pharmacological methods are inappropriate because they lack tissue specificity. The injection of specific antibodies or antisense oligonucleotides against components of peptide systems in tissue exerts more local effects. However, these procedures are hampered by low efficiency, a short duration of action and side effects elicited by the injection procedure itself. Therefore, transgenic techniques have been increasingly applied for the functional analysis of local peptide systems. Transgenic techniques will be briefly described in the following sections and the suitability of the transgenic approach will be illustrated by the description of transgenic animal models with targeted modifications in the reninangiotensin system.

\section{Transgenic technology}

Two different approaches can be used to modify the genotype of an animal: 1) the microinjection of DNA in the nucleus of a fertilized oocyte, and 2) the targeted modification of a gene in its chromosomal location by homologous recombination in embryonic stem cells, which are subsequently integrated into early embryos. In both cases the modified embryos develop into transgenic animals after transfer into foster mothers.

\section{Microinjection technique}

The technique for the production of transgenic animal models by the integration of foreign gene sequences into the genome of mammals has been established for more than 15 years (1-4). Most of the experiments since then have been performed on mice (reviewed in 5-8). However, the technique has also been extended to species like rats (9-12), rabbits $(13,14)$, sheep $(14,15)$, goats (16), cattle (17), and pigs (13,14,18-20). The development of transgenic technology for the rat was especially important for cardiovascular research, in which the mouse only plays a minor role mainly because of its limited size. The most common method to produce transgenic mammals is the microinjection of DNA constructs into the paternal pronucleus of a fertilized oocyte (Figure 1). The injected zygotes are implanted into the oviduct of foster mothers and brought to term. For mice and rats, about $20 \%$ of the offspring integrate the transgene into their genome and pass it to their offspring, thereby establishing a transgenic line. Several copies of the foreign DNA are integrated at one site in a chromosome. The expression of the transgene, however, does not only depend on the copy number but also on the chromosomal environment at the integration site and is therefore not absolutely predictable. In most cases the goal is to overexpress the gene of interest. The integration of the transgene with its own regulatory elements leads to an increased number of gene copies in the genetically modified animal and to a higher expression with conserved tissue specificity. To overexpress a gene in a specific organ or cell type, the respective cDNA is fused to a tissue-specific promoter and this construct is used for the production of transgenic animals. Table 1 summarizes examples of promoters used for transgene expression in different tissues. Furthermore, inducible promoter systems are available, which allow to control transgene expression by the application of substances to the genetically modified animals.

Recently, the microinjection technique has also been applied to downregulate gene expression in mice and rats. The method used is the expression of antisense RNAs in transgenic animals by the injection of con- 
Table 1 - Promoters of tissue-specific expression of transgenes.

\begin{tabular}{llll}
\hline Promoter & Abbreviation & Cell type of highest activity & Reference \\
\hline Neuron-specific enolase & NSE & Neurones & (112) \\
Tubulin $\alpha 1$ & T- $\alpha 1$ & Neurones & $(113)$ \\
Glial-fibrillary acidic protein & GFAP & Astrocytes & $(25,114,115)$ \\
Myosin light chain-2 & MLC2 & Cardiomyocytes & $(116-118)$ \\
Preproendothelin-1 & ET-1 & Endothelial cells & $(119)$ \\
Tie & tie & Endothelial cells & $(120)$ \\
SM22 $\alpha$ & SM22 & Vascular smooth muscle cells & $(121)$ \\
$\alpha 1-A n t i t r y p s i n$ & $\alpha 1-A T$ & Hepatocytes & $(91,122)$ \\
Albumin & ALB & Hepatocytes & $(123)$ \\
Side-chain-cleavage enzyme & SCC & Steroidogenic cells & $(124,125)$ \\
Kidney-androgen responsive protein & KAP & Renal proximal tubular cells & (126)
\end{tabular}

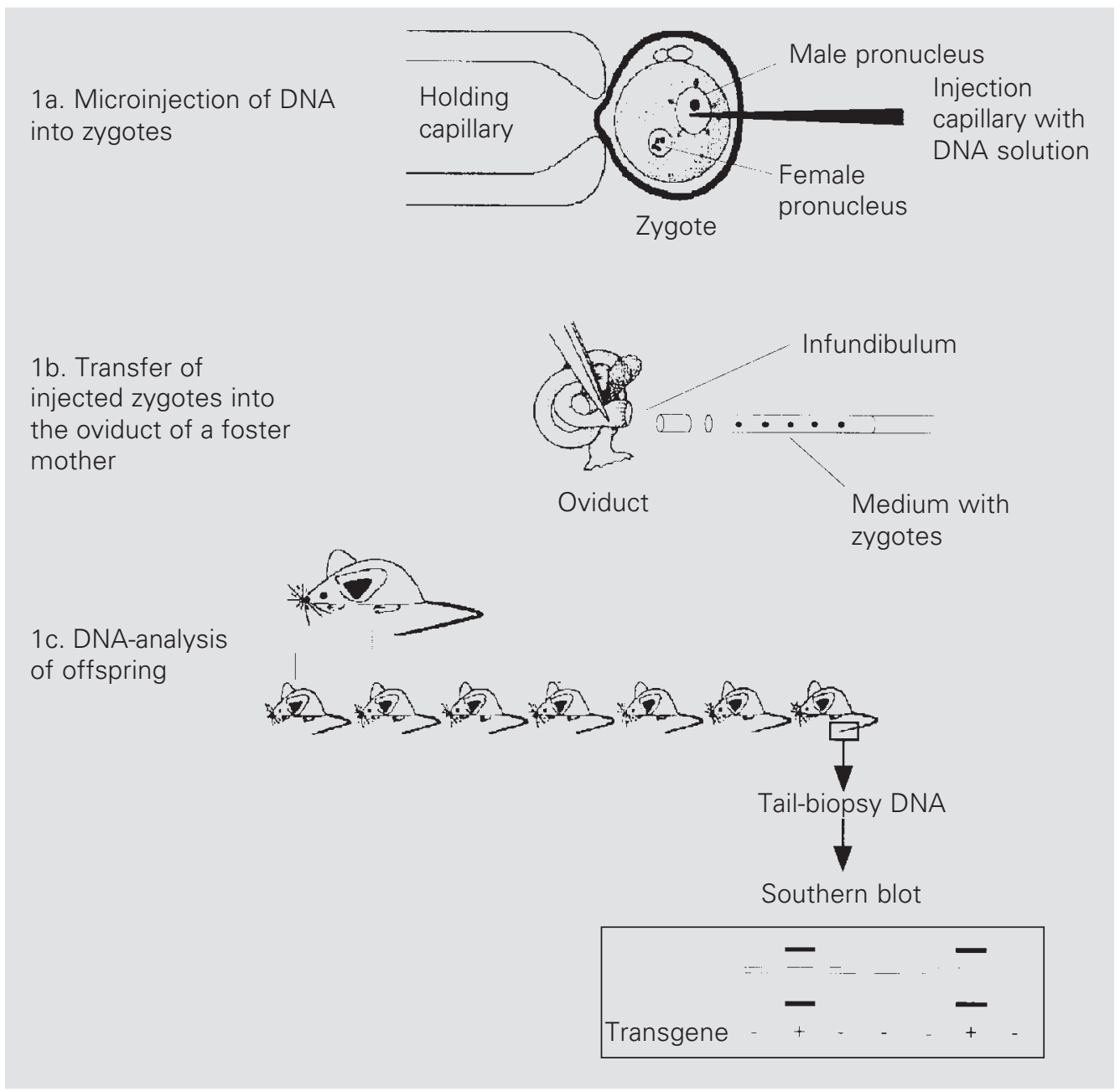

Figure 1 - Generation of transgenic rodents. A few copies of the DNA construct are injected into the male pronucleus (1a) of a fertilized oocyte, which is then transferred into the oviduct of a pseudopregnant foster mother (1b). The resulting offspring is analyzed for the presence of the transgene by Southern blotting with a specific probe (1c). 
structs in which a part of the cDNA of interest has been fused in opposite orientation to a strong promoter. This results in the synthesis of an RNA complementary to the transcript from the gene of interest. The two RNAs will form a duplex in cells, which either blocks processing or translation of the mRNA or is a target for double-stranded RNA-editing enzymes (Figure 2). These enzymes covalently modify the mRNA in most cases leading to their functional destruction (21). Although the ablation of gene expression by antisense RNA is never complete, several animal models with physiological alterations have been successfully developed using this method also in the cardiovascular system (12,22-25) (see also below).

\section{Gene targeting in embryonic stem cells (knockout technology)}

The total ablation of genes was made possible by the recently developed knockout technology. Two new methods are the basis for this novel transgenic technique, the permanent culture of totipotent embryonic cells able to build up a whole animal $(26,27)$ and the targeted disruption of a gene by homologous recombination $(28,29)$. For homolo- gous recombination a DNA construct containing large parts of the respective gene together with selectable marker genes is transfected into embryonic stem (ES) cells. In most cases the marker genes are used to create a null mutation of the targeted gene; however, also more subtle genetic alterations are possible. The cells, in which the very rare event of homologous recombination, i.e., the exchange of the endogenous gene with the DNA construct has taken place, are selected using the marker genes. The genotype is confirmed by PCR and Southern blotting and the mutated ES cells are microinjected into or fused with early embryos. After transfer to the uterus, the embryos are brought to term by foster mothers. The resulting chimeras between the host embryo and the ES cells are recognized by coat color and are used to develop a line of homozygous animals carrying the mutation in both alleles of the targeted gene after two subsequent generations. Such animals are the most powerful models to study the function of a gene. However, the method has also disadvantages: 1) the gene is mutated throughout ontogeny and in all organs of the animals. Thus, only the earliest role played by an essential gene during ontogeny can be detected in the knockout ani-
Figure 2 - Mechanisms of antisense RNA action. Antisense RNA covering two exons can inhibit splicing of the target premRNA in the nucleus (2a). In the cytoplasm it can inhibit ribosome binding to the cap structure (closed circle) and the $5^{\prime}$-untranslated part of the mRNA (2b) or it can block the elongation of the nascent protein chain (2c). In addition, the extended doublestranded RNA formed by the antisense RNA and its target mRNA represent a substrate for double-stranded RNA editing enzymes (unwindase), which modify both RNAs by deaminating adenosine residues (21). The resulting inosine bases form base pairs with guanine leading to the synthesis of mutated proteins from such altered mRNAs (2d).

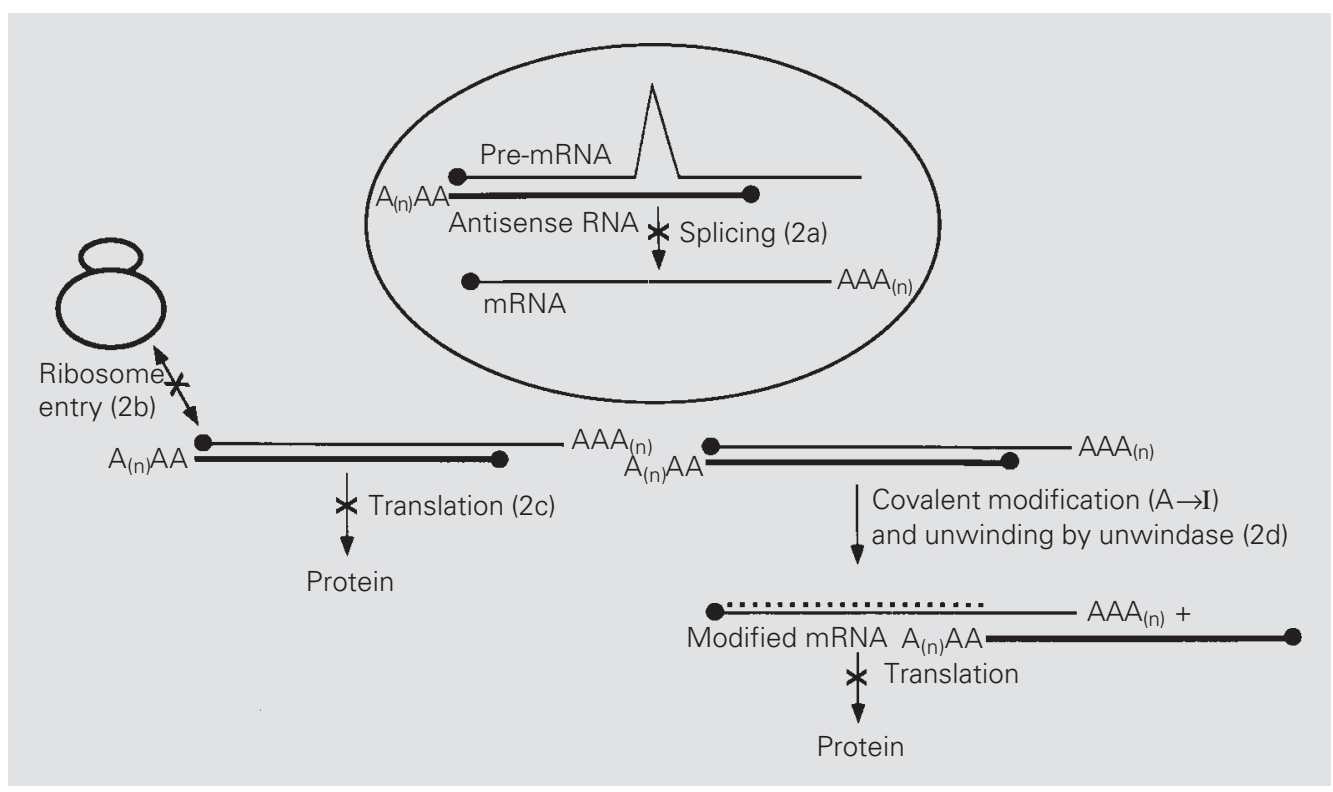


mals. Its function in adulthood cannot be studied since in many cases the homozygous animals will not reach this stage. To solve this problem conditional knockout techniques have very recently been designed and already successfully employed using the CreloxP system, a recombination system of bacteriophage $\mathrm{P} 1$, which allows the tissue-specific or developmental stage-dependent ablation of a gene (30). 2) Thus far, the technique is only available for the mouse and even in the mouse only cells derived from one strain $(129 / \mathrm{Sv})$ are routinely used for such experiments. A lot of effort has been devoted to the development of ES cells from other species, e.g. the rat (31), for the reasons already state above. However, germlinecompetent ES-cells could not be established from any other animal and there is no particular reason to explain this failure. The application of a novel technique on the basis of transgenic animals, which allows the selection of totipotent cells during the development of ES-cell lines may help solve this problem.

\section{Transgenic and knockout animal models for the renin-angiotensin system}

The generation of active angiotensin peptides is achieved by a small number of proteins all of which have been already overexpressed as well as inactivated by transgenic technology. The sole precursor angiotensinogen, synthesized mainly in the liver, is cleaved by renin produced by the juxtaglomerular cells of the kidney resulting in the liberation of the inactive decapeptide angiotensin I. The active peptide angiotensin II is generated by the proteolytic ablation of the two carboxyterminal amino acids of angiotensin I by the endothelium-associated angiotensin-converting enzyme (ACE). Angiotensin II elicits its effects via two different receptor subtypes, AT1, which is expressed in all main target organs like kidney, heart, brain, adrenal cortex, and vessel wall and represents the receptor responsible for nearly all known actions of the peptide, and AT2, which is mainly restricted to certain brain regions and the adrenal medulla. In the following section transgenic animals with changes in the expression of the genes for components of the renin-angiotensin system as well as the conclusions drawn from these models will be discussed.

\section{Angiotensinogen}

The angiotensinogen gene of mice (32), rats $(33,34)$, and humans $(11,35,36)$ has been expressed in transgenic mice $(32,33,35,36)$ and rats (11) under the control of its own $(11,32,34-36)$ or of the mouse metallothionein (mMT-1) promoter (33). All rodents transgenic for human angiotensinogen remained normotensive even though some of them exhibited very high levels of the human protein in plasma. This finding corroborated previous biochemical studies showing that human renin and angiotensinogen do not interact with their rodent counterparts (37, 38). Only when the animals carrying the human angiotensinogen gene are crossbred with human-renin transgenic rats or mice do the animals produce an excess of angiotensin II and become hypertensive (39-43; see below). The only transgenic animal carrying solely an angiotensinogen gene and being hypertensive was produced by Kimura et al. (34) by the introduction of the rat homolog into the mouse genome. Despite exhibiting equally high levels of circulating angiotensin II, the transgenic mouse model harboring the rat angiotensinogen gene under the control of the mMT-1 promoter is normotensive (33). The reason for this discrepancy may be the different tissue-specificity of expression of the two transgenes: while the foreign promoter leads to ectopic expression, the rat angiotensinogen promoter directs the production of additional angiotensin II to sites which are responsive to this 
peptide. A tissue in which the correct site of expression is especially important is the brain. Using another transgenic animal model we could show that angiotensinogen in the brain plays an important role in blood pressure regulation. We produced a transgenic rat expressing an antisense RNA against angiotensinogen (44) exclusively in the brain with the help of the promoter for the glial-fibrillary associated protein (GFAP). High expression of this antisense RNA led to a brainspecific downregulation of angiotensinogen protein, a decrease in blood pressure (25), and a mild diabetes insipidus (45).

The decrease in blood pressure in these rats was comparable to the decrease observed in mice carrying only one functional angiotensinogen allele (46). They were produced in a gene-titration experiment together with mice having zero, two, three, and four alleles of this gene. Circulating angiotensinogen levels as well as blood pressure correlated strongly with the gene dose, supporting the important role of this protein in blood pressure regulation at least in rodents. Very low blood pressure levels were measured in angiotensinogen-knockout mice which were produced by three groups independently (4648). Depending on the genetic background the targeted ablation of this protein even produced a lethal phenotype, the cause of which is not yet clarified but may be related to morphological alterations observed in the kidney. Several groups have rescued the phenotype of these knockout mice by crossbreeding them with transgenic mice expressing the rat angiotensinogen gene (49) or the human renin and angiotensinogen genes (50). The latter experiment resulted in mice in which the only active renin-angiotensin system is derived from human genes.

\section{Renin}

Transgenic mice $(33,40,43,51-57)$ and rats $(9,11)$ carrying renin genes from rats (33), mice (9,54-57), and man (11,40,43,51-
53) have been generated. The first animal models were designed to analyze the pattern of differential expression of mouse renin genes. The mouse is the only species analyzed so far with more than one renin gene. There are strains with one renin gene, Ren$1^{\mathrm{c}}$, and strains bearing two genes, Ren- $1^{\mathrm{d}}$ and Ren-2, closely linked on chromosome 1 since they originate from an evolutionarily recent gene duplication. The genes are differentially expressed and transgenic experiments showed that DNA sequences in the promoter as well as in the transcribed regions are required for a correct tissue specificity of expression. Transgenic mice with the whole Ren-2 gene including 5.3 (54) or $2.5 \mathrm{~kb}$ $(55,56)$ of the promoter region and all exons and introns or with a $4.6-\mathrm{kb}$ promoter fragment and the SV40 T-antigen as a reporter gene express the transgene correctly (5861 ), while animals with only $2.5 \mathrm{~kb}$ of the promoter and the same reporter gene show ectopic expression (62). Thus, there seems to be a redundancy of tissue-specific elements in the promoter and in the transcribed region as $2.5 \mathrm{~kb}$ of promoter are only sufficient for correct expression in concert with all exons and introns, while longer 5'-flanking regions are independent of other parts of the Ren-2 gene. Recent studies have revealed possible candidates for such tissue-specific elements in the distant promoter (63) as well as in intron I of the gene (64-66). Comparable results have also been published for the Ren- $1^{\mathrm{d}}$ gene as $5 \mathrm{~kb}$ of the promoter led to the correct expression in transgenic mice only in the presence of the whole transcribed region but not fused to a chloramphenicol acetyltransferase (CAT) reporter gene (57).

While for none of these mouse models blood pressure values have been reported, the arterial pressure of mice carrying the rat renin gene under the control of the mMT-1 promoter was determined and found to be normal, which may be explained by species specificity of the renin-angiotensinogen interaction (33). When these mice were crossed 
with mMT-1-angiotensinogen transgenic animals (see above) the double transgenic mice became hypertensive. The same holds true for double transgenic mice and rats with the human renin and angiotensinogen transgenes also because of the species specificity of the enzyme-substrate reaction $(39,40,42,43)$. These "humanized" rodent models independently developed by several groups are useful tools to study the local production and action of angiotensin II in tissues and to test human renin inhibitors, which cannot be tested in normal rodents because of species specificity $(11,67)$. In addition, such animals may help elucidate the cause for specific forms of pregnancy-induced hypertension (68).

Another important model for the study of tissue-based renin-angiotensin systems is a transgenic rat carrying the murine Ren- 2 gene, TGR(mREN2)27 (9). These animals develop severe hypertension and cardiovascular hypertrophy despite low levels of circulating angiotensin II. However, the generation of this peptide is massively enhanced in several tissues, like adrenal glands and brain, leading to numerous physiological changes (6990). These changes as well as the very high circulating levels of prorenin, the inactive precursor of renin, may contribute to the hypertensive phenotype of TGR(mREN2)27, although its etiology has not been fully clarified. Veniant et al. (91) have shown that prorenin when expressed in the liver of transgenic rats with the use of the $\alpha 1$-antitrypsin promoter and reaching similarly high circulating levels can cause a degree of cardiovascular hypertrophy comparable to that observed in TGR(mREN2)27 probably because it can be activated in peripheral tissues. Others have presented evidence that elevated angiotensin levels in brain $(73,77$, 78), kidney $(69,76,77)$, and adrenal gland $(74,75,77,89)$ of TGR(mREN2)27 also play important roles in the development of hypertension. Studies using the specific downregulation of the renin-angiotensin system in single organs like the one presented above
(25) may help elucidate the relative importance of the local angiotensin-generating systems in the pathogenesis of hypertension in TGR(mREN2)27.

As mentioned above, ES cells are almost exclusively from strain $129 / \mathrm{Sv}$, which contains two renin genes. Although both genes have been separately inactivated by gene targeting, a total renin-knockout by simple crossbreeding is precluded by the close linkage of the two genes. The Ren- 2 knockout mice are healthy and normotensive and only exhibit increased active renin and reduced prorenin levels in plasma (92). Animals lacking Ren- $1{ }^{\mathrm{d}}$ have been produced by two groups independently $(93,94)$. While the resulting animals were normotensive in one experiment (93), in the other study, they showed morphological alterations in the kidney exemplified by a lack of secretory granules in the juxtaglomerular cells and hypertrophy of the macula densa as well as enhanced circulating prorenin levels, and the females became slightly hypotensive (94). The quite mild phenotype of both knockout models argues in favor of a high redundancy of the two renin genes, i.e., the presence of one gene can largely compensate for the lack of the other.

\section{ACE}

Transgenic rats overexpressing ACE predominantly in the heart have recently been produced and the phenotype has been partially reported (95). Despite very high levels of ACE activity in the heart there are no morphological alterations of this organ unless it is pressure overloaded by aortic banding. This treatment results in a significantly higher hypertrophic response in ACE-transgenic rats than in control animals, supporting the important role of angiotensin II in this process postulated by earlier pharmacological and transgenic (see below) studies.

Transgenic mice were generated to analyze the testis-specific promoter in intron 13 of 
the ACE gene responsible for the production of a shorter but still active protein in this organ (96-99). ACE seems to play an important role in the testis since male ACE-knockout mice are infertile (100). Furthermore, the animals are hypotensive and develop kidney abnormalities comparable to those of the angiotensinogen knockout animals (101). In a very recent experiment the same phenotype could be shown for mice in which only the membrane anchor of the ACE-protein was deleted by knockout technology (102). These animals have still normal circulating ACE levels but lack the membrane-bound form, which, according to this report, is the only functionally important isoform of the enzyme.

\section{Angiotensin receptors}

The only reported transgenic animal models overexpressing AT1-receptors have targeted its expression to the heart by the use of the $\alpha$-myosin-heavy chain promoter (103, 104). However, the phenotypes of the transgenic mouse and the transgenic rat thus generated were dramatically different. The mice exhibit a drastic cardiac hypertrophy and die of severe bradycardia early in life (103), whereas the rats appear absolutely normal unless the heart is pressure overloaded by aortic banding which, as is the case for ACEtransgenic rats, leads to a more pronounced hypertrophy than in control animals (104). The difference might be related to the different source of the AT1 receptor: while for the transgenic mouse the murine AT1A-cDNA receptor was used, the rat overexpressed the human homolog.

When the AT2 receptor is overexpressed in the heart the resulting transgenic mice show no obvious morphological alterations but they are less sensitive to angiotensin-II induced blood-pressure elevation indicating that the AT2 receptor counteracts the AT1 receptor at least in this respect (105).

Several groups have inactivated the AT1 receptor by gene targeting in mice (106-
108). Like for the renin gene, these studies are hampered by the existence of two different genes coding for AT receptors in this species and also in rats, AT1A and AT1B. The knockout experiments revealed, however, that the AT1A receptor is the more important isoform since the gene-targeted mice showed a comparably severe phenotype as angiotensinogen- or ACE-knockout animals. Furthermore, mice lacking AT1B show no obvious phenotype (109). Double knockout animals will elucidate whether the slightly less severe kidney alterations observed in AT1A-deficient mice compared to mice lacking angiotensinogen are due to a compensatory action of AT1B receptors in this organ.

The AT2 receptor has also been inactivated by two groups independently (110, 111). In addition to behavioral abnormalities, AT2 deficiency results in a more pronounced pressor response to angiotensin-II infusion, corroborating the antagonism between AT1 and AT2.

\section{Conclusions}

The transgenic animal models for the renin-angiotensin system established so far have provided novel information concerning the function of this peptide system active in cardiovascular regulation. The most important finding is the importance of tissuebased angiotensin generation in contrast to the circulatory system. Tissue-specific ablation of the renin-angiotensin system by antisense RNA expression or conditional knockout technology will facilitate the study of these functionally important peptide systems, e.g., in the brain, adrenal gland, vascular wall, heart, and kidney. Existing as well as future animal models will increase our understanding of the basic cardiovascular regulation and of the mechanisms involved in the development of hypertension and may be of help to design new therapeutic strategies for the therapy of cardiovascular diseases. 


\section{References}

1. Gordon JW \& Ruddle FH (1983). Gene transfer into mouse embryos: production of transgenic mice by pronuclear injection. Methods in Enzymology, 101: 411433.

2. Wagner EF, Stewart TA \& Mintz B (1981). The human b-globin gene and a functional viral thymidine kinase gene in developing mice. Proceedings of the National Academy of Sciences, USA, 78: 5016-5020.

3. Costantini F \& Lacy E (1981). Introduction of a rabbit $ß$-globin gene into the mouse germ line. Nature, 294: 92-94.

4. Harbers K, Jähner D \& Jaenisch R (1981). Microinjection of cloned retroviral genomes into mouse zygotes: integration and expression in the animal. Nature, 293: 540-542.

5. Palmiter RD \& Brinster RL (1986). Germline transformation of mice. Annual Review of Genetics, 20: 465-499.

6. Hanahan D (1989). Transgenic mice as probes into complex systems. Science, 246: 1265-1275.

7. Mockrin SC, Dzau VJ, Gross KW \& Horan MJ (1991). Transgenic animals: new approaches to hypertension research. Hypertension, 17: 394-399.

8. Franz WM, Mueller OJ, Hartong R, Frey N \& Katus HA (1997). Transgenic animal models: new avenues in cardiovascular physiology. Journal of Molecular Medicine, 75: 115-129.

9. Mullins JJ, Peters J \& Ganten D (1990). Fulminant hypertension in transgenic rats harbouring the mouse Ren-2 gene. Nature, 344: 541-544.

10. Hammer RE, Maika SD, Richardson JA, Tang J \& Taurog JD (1990). Spontaneous inflammatory disease in transgenic rats expressing HLA-B27 and human b2m: An animal model of HLA-B27-associated human disorders. Cell, 63: 1099-1112.

11. Ganten D, Wagner J, Zeh K, Bader M, Michel J-B, Paul M, Zimmermann F, Ruf $P$, Hilgenfeldt $U$, Ganten $U$, Kaling $M$, Bachmann S, Fukamizu A, Mullins JJ \& Murakami K (1992). Species specificity of renin kinetics in transgenic rats harboring the human renin and angiotensinogen genes. Proceedings of the National Academy of Sciences, USA, 89: 7806-7810.

12. Matsumoto K, Kakidani $H$, Anzai M, Nakagata N, Takahashi A, Takahashi Y \& Miyata K (1995). Evaluation of an antisense RNA transgene for inhibiting growth hormone gene expression in transgenic rats. Developmental Genetics, 16: $273-277$
13. Weidle UH, Lenz H \& Brem G (1991). Genes encoding a mouse monoclonal antibody are expressed in transgenic mice, rabbits and pigs. Gene, 98: 185191.

14. Hammer RE, Pursel VG, Reynolds RC, Rexroad CEJ, Wall RJ, Bolt DJ, Ebert KM, Palmiter RD \& Brinster RL (1985). Production of transgenic rabbits, sheep and pigs by microinjection. Nature, 315: 680-683.

15. Clark A, Bessos H, Bishop J, Brown P, Harris S, Lathe R, McClenaghan M, Prowse C, Simons J, Whitehaw C \& Wilmut I (1989). Expression of human anti-hemophilic factor IX in the milk of transgenic sheep. Bio/Technology, 7: 487492.

16. Ebert KM, Selgrath JP, DiTullio P, Denman J, Smith TE, Memon MA, Schindler JE, Monastersky GM, Vitale JA \& Gordon K (1991). Transgenic production of a variant of human tissue-type plasminogen activator in goat milk: Generation of transgenic goats and analysis of expression. Bio/ Technology, 9: 835-838.

17. Krimpenfort $P$, Rademakers $A$, Eyestone W, van der Schans $A$, van den Broek S, Kooiman P, Kootwijk E, Platenburg G, Pieper F, Strijker R \& de Boer H (1991). Generation of transgenic dairy cattle using in vitro embryo production. Bio/Technology, 9: 844-847.

18. Miller KF, Bolt DJ, Pursel VG, Hammer RE, Pinkert CA, Palmiter RD \& Brinster RL (1989). Expression of human or bovine growth hormone gene with a mouse metallothionein-1 promoter in transgenic swine alters the secretion of porcine growth hormone and insulin-like growth factor-I. Journal of Endocrinology, 120: 481-488.

19. Brem G, Brenig B, Goodman H, Selden R, Graf F, Kruff B, Springman K, Hondele J, Meyer J, Winnacker E \& Kraublich $H$ (1985). Production of transgenic rabbits and pigs. Zuchthygiene, 20: 251-252.

20. Wall R, Pursel V, Shamay A, McKnight R, Pittius C \& Henninghausen L (1991). Highlevel synthesis of a heterologous milk protein in the mammary gland of transgenic swine. Proceedings of the National Academy of Sciences, USA, 88: 1696-1700.

21. Bass BL \& Weintraub $H$ (1988). An unwinding activity that covalently modifies its double-stranded RNA substrate. Cell, 55: 1089-1098.

22. Munir MI, Rossiter BJF \& Caskey CT (1990). Antisense RNA production in transgenic mice. Somatic Cell and Molec- ular Genetics, 16: 383-394.

23. Katsuki M, Sato M, Kimura M, Yokoyama M, Kobayashi K \& Nomura T (1988). Conversion of normal behavior to shiverer by myelin basic protein antisense cDNA in transgenic mice. Science, 241: 593-595.

24. Pepin M-C, Pothier F \& Barden N (1992). Impaired type II glucocorticoid-receptor function in mice bearing antisense RNA transgene. Nature, 355: 725-728.

25. Schinke M, Böhm M, Bricca G, Lippoldt A, Bader M \& Ganten D (1995). Antisense RNA expression modulates angiotensinogen synthesis in cell culture and in the brain of transgenic rats. Hypertension, 26: 547 (Abstract).

26. Evans MJ \& Kaufman MH (1981). Establishment in culture of pluripotential cells from mouse embryos. Nature, 292: 154156.

27. Bradley A, Evans M, Kaufman $\mathrm{MH}$ \& Robertson E (1984). Formation of germline chimaeras from embryo-derived teratocarcinoma cell lines. Nature, 309: 255256.

28. Thomas KR \& Capecchi MR (1987). Sitedirected mutagenesis by gene targeting in mouse embryo-derived stem cells. Cell, 51: 503-512.

29. Mansour SL, Thomas KR \& Capecchi MR (1988). Disruption of the proto-oncogene int-2 in mouse embryo-derived stem cells: A general strategy for targeting mutations to non-selectable genes. Nature, 336: 348-352.

30. Rajewsky K, Gu H, Kühn R, Betz UA, Müller W, Roes J \& Schwenk F (1996). Conditional gene targeting. Journal of Clinical Investigation, 98: 600-603.

31. Brenin DR, Bader M, Hübner N, Levan G \& lannaccone PM (1997). Rat embryonic stem cells: A progress report. Transplantation Proceedings, 29: 1761-1765.

32. Clouston WM, Lyons IG \& Richards R (1989). Tissue-specific and hormonal regulation of angiotensinogen minigenes in transgenic mice. EMBO Journal, 8: 3337-3343.

33. Ohkubo H, Kawakami H, Kakehi Y, Takumi T, Arai H, Yokota Y, Iwai M, Tanabe $Y$, Masu M, Hata J, Iwao H, Okamoto $H$, Yokoyama $M$, Nomura $T$, Katsuki $M$ \& Nakanishi S (1990). Generation of transgenic mice with elevated blood pressure by introduction of the rat renin and angiotensinogen genes. Proceedings of the National Academy of Sciences, USA, 87: 5153-5157.

34. Kimura S, Mullins JJ, Bunnemann B, 
Metzger R, Hilgenfeldt $U$, Zimmermann F, Jacob H, Fuxe K, Ganten D \& Kaling M (1992). High blood pressure in transgenic mice carrying the rat angiotensinogen gene. EMBO Journal, 11: 821-827.

35. Takahashi S, Fukamizu A, Hasegawa T, Yokoyama M, Nomura T, Katsuki M \& Murakami K (1991). Expression of the human angiotensinogen gene in transgenic mice and transfected cells. Biochemical and Biophysical Research Communications, 180: 1103-1109.

36. Yang G, Merrill DC, Thompson MW, Robillard JE \& Sigmund CD (1994). Functional expression of the human angiotensinogen gene in transgenic mice. Journal of Biological Chemistry, 269: $32497-$ 32502.

37. Oliver WJ \& Gross F (1966). Unique specificity of mouse angiotensinogen to homologous renin. Proceedings of the Society for Experimental Biology and Medicine, 122: 923-926.

38. Hatae T, Takimoto E, Murakami K \& Fukamizu A (1994). Comparative studies on species-specific reactivity between renin and angiotensinogen. Molecular and Cellular Biochemistry, 131: 43-47.

39. Bohlender J, Fukamizu A, Lippoldt A, Nomura T, Dietz R, Menard J, Murakami K, Luft FC \& Ganten D (1997). High human renin hypertension in transgenic rats. Hypertension, 29: 428-434.

40. Thompson MW, Smith SB \& Sigmund CD (1996). Regulation of human renin mRNA expression and protein release in transgenic mice. Hypertension, 28: 290-296.

41. Uehara S, Mino N, Tsuchida M, Nishikibe M, Fukamizu A, Murakami K \& Ikemoto F (1995). Development of polyuria in Tsukuba hypertensive mice carrying human renin and angiotensinogen genes. Clinical and Experimental Pharmacology and Physiology, 22 (Suppl 1): S12-S14.

42. Merrill DC, Thompson MW, Carney CL, Granwehr BP, Schlager G, Robillard JE \& Sigmund CD (1996). Chronic hypertension and altered baroreflex responses in transgenic mice containing the human renin and human angiotensinogen genes. Journal of Clinical Investigation, 97: 10471055.

43. Fukamizu A, Sugimura K, Takimoto E, Sugiyama F, Seo MS, Takahashi S, Hatae T, Kajiwara N, Yagami K \& Murakami K (1993). Chimeric renin-angiotensin system demonstrates sustained increase in blood pressure of transgenic mice carrying both human renin and human angiotensinogen genes. Journal of Biological Chemistry, 268: 11617-11621.
44. Schinke M, Böhm M, Bricca G, Ganten D \& Bader M (1996). Permanent inhibition of angiotensinogen synthesis by antisense RNA expression. Hypertension, 27: 508-513.

45. Baltatu O, Schinke M, Rascher W, Ganten D \& Bader M (1997). Transgenic inhibition of brain angiotensinogen leads to diabetes insipidus. Hypertension, 30: 480 (Abstract).

46. Kim H-S, Krege JH, Kluckman KD, Hagaman JR, Hodgin JB, Best CF, Jennette JC, Coffman TM, Maeda N \& Smithies O (1995). Genetic control of blood pressure and the angiotensinogen locus. Proceedings of the National Academy of Sciences, USA, 92: 2735-2739.

47. Tanimoto K, Sugiyama F, Goto Y, Ishida J, Takimoto E, Yagami K, Fukamizu A \& Murakami K (1994). Angiotensinogen-deficient mice with hypotension. Journal of Biological Chemistry, 269: 31334-31337.

48. Niimura F, Labosky PA, Kakuchi J, Okubo S, Yoshida H, Oikawa T, Ichiki T, Naftilan AJ, Fogo A, Inagami $T$, Hogan BLM \& Ichikawa I (1995). Gene targeting in mice reveals a requirement for angiotensin in the development and maintenance of kidney morphology and growth factor regulation. Journal of Clinical Investigation, 96: 2947-2954

49. Bader M, Kang N, Walther T, Fukamizu A, Murakami K \& Ganten D (1996). Phenotypic rescue of angiotensinogen-knockout mice by tissue-specific expression of a rat angiotensinogen transgene. Hypertension, 28: 708 (Abstract).

50. Davisson RL, Kim HS, Krege JH, Lager DJ, Smithies O \& Sigmund CD (1997). Complementation of reduced survival, hypotension, and renal abnormalities in angiotensinogen-deficient mice by the human renin and human angiotensinogen genes. Journal of Clinical Investigation, 99: 1258-1264.

51. Thompson MW, Smith SB \& Sigmund CD (1996). Regulation of human renin mRNA expression and protein release in transgenic mice. Hypertension, 28: 290-296

52. Sigmund CD, Jones CA, Kane CM, Wu C, Lang JA \& Gross KW (1992). Regulated tissue- and cell-specific expression of the human renin gene in transgenic mice. Circulation Research, 70: 1070-1079.

53. Fukamizu A, Seo MS, Hatae T, Yokoyama $M$, Nomura $T$, Katsuki $M$ \& Murakami $K$ (1989). Tissue-specific expression of the human renin gene in transgenic mice. Biochemical and Biophysical Research Communications, 165: 826-832.

54. Mullins JJ, Sigmund CD, Kane-Haas C,
McGowan RA \& Gross KW (1989). Expression of the DBA/2J Ren-2 gene in the adrenal gland of transgenic mice. EMBO Journal, 8: 4065-4072.

55. Tronik D \& Rougeon F (1988). Thyroxine and testosterone transcriptionally regulate renin gene expression in the submaxillary gland of normal and transgenic mice carrying extra copies of the Ren2 gene. FEBS Letters, 234: 336-340.

56. Tronik D, Dreyfus M, Babinet C \& Rougeon F (1987). Regulated expression of the Ren-2 gene in transgenic mice derived from parental strains carrying only the Ren-1 gene. EMBO Journal, 6: 983987

57. Miller CC, Samani NJ, Carter AT, Brooks JI \& Brammar WJ (1989). Modulation of mouse renin gene expression by dietary sodium chloride intake in one-gene, twogene and transgenic animals. Journal of Hypertension, 7: 861-863.

58. Jacob HJ, Sigmund CD, Shockley TR, Gross KW \& Dzau VJ (1991). Renin promoter SV40 T-antigen transgenic mouse. Hypertension, 17: 1167-1172.

59. Sigmund $C D$, Jones $C A$, Jacob $\mathrm{HJ}$ Ingelfinger J, Kim U, Gamble D, Dzau VJ \& Gross KW (1991). Pathophysiology of vascular smooth muscle in renin promoter-T-antigen transgenic mice. American Journal of Physiology, 260: F249F257.

60. Sigmund $C D$, Jones CA, Fabian JR, Mullins JJ \& Gross KW (1990). Tissue and cell specific expression of a renin promoter-reporter gene construct in transgenic mice. Biochemical and Biophysical Research Communications, 170: 344-350.

61. Sigmund CD, Jones CA, Mullins JJ, Kim U \& Gross KW (1990). Expression of murine renin genes in subcutaneous connective tissue. Proceedings of the National Academy of Sciences, USA, 87: 79937997

62. Sola C, Tronik D, Dreyfus M, Babinet C \& Rougeon F (1989). Renin-promoter SV40 large T-antigen transgenes induce tumors irrespective of normal cellular expression of renin genes. Oncogene Research, 5: 149-153.

63. Yan Y, Jones CA, Sigmund CD, Gross KW \& Catanzaro DF (1997). Conserved enhancer elements in human and mouse renin genes have different transcriptional effects in AS4.1 cells. Circulation Research, 81: 558-566.

64. Voigtländer T, Ripperger A, Ganten D \& Bader M (1995). Transcriptional silencer in intron I of the rat renin gene. Advances in Experimental Medicine and Biology, 
377: 285-292.

65. Germain S, Philippe J, Fuchs S, Lengronne A, Corvol P \& Pinet F (1997). Regulation of human renin secretion and gene transcription in Calu-6 cells. FEBS Letters, 407: 177-183.

66. Lang JA, Ying L-H, Morris BJ \& Sigmund CD (1996). Transcriptional and posttranscriptional mechanisms regulate human renin gene expression in Calu-6 cells. American Journal of Physiology, 271: F94F100.

67. Bohlender J, Menard J, Luft FC \& Ganten D (1997). Dose effects of human renin in rats transgenic for human angiotensinogen. Hypertension, 29: 1031-1038.

68. Takimoto E, Ishida J, Sugiyama F, Horiguchi H, Murakami K \& Fukamizu A (1996). Hypertension induced in pregnant mice by placental renin and maternal angiotensinogen. Science, 274: 995-998.

69. Gross V, Lippoldt A, Bohlender J, Ganten D, Ganten U \& Luft FC (1996). The reninangiotensin system and renal function in transgenic (mRen2)27 rats. Experimental Nephrology, 4 (Suppl 1): 20-26.

70. Struijker Boudier HA, van Essen H, Fazzi G, De Mey JG, Qiu HY \& Levy BI (1996). Disproportional arterial hypertrophy in hypertensive mRen-2 transgenic rats. Hypertension, 28: 779-784.

71. Li P, Morris M, Diz DI, Ferrario CM, Ganten D \& Callahan MF (1996). Role of paraventricular angiotensin AT1 receptors in salt-sensitive hypertension in mRen-2 transgenic rats. American Journal of Physiology, 270: R1178-R1181.

72. Ohta K, Kim S, Wanibuchi H, Ganten D \& Iwao H (1996). Contribution of local reninangiotensin system to cardiac hypertrophy, phenotypic modulation, and remodeling in TGR(mRen2)27 transgenic rats. Circulation, 94: 785-791.

73. Diz DI, Falgui B, Bosch SM, Westwood BM, Kent J, Ganten D \& Ferrario CM (1997). Hypothalamic substance P release. Attenuated angiotensin responses in mRen2(27) transgenic rats. Hypertension, 29: 510-513.

74. Tokita Y, Franco-Saenz R, Mulrow PJ \& Ganten D (1994). Effects of nephrectomy and adrenalectomy on the renin-angiotensin system on transgenic rats TGR(mRen2)27. Endocrinology, 134: 253257.

75. Bachmann S, Peters J, Engler E, Ganten D \& Mullins J (1992). Transgenic rats carrying the mouse renin gene - Morphological characterization of a low renin hypertension model. Kidney International, 41: 24-36.
76. Gross V, Lippoldt A, Schneider W \& Luft FC (1995). Effect of captopril and angiotensin II receptor blockade on pressure natriuresis in transgenic TGR(mREN-2)27 rats. Hypertension, 26: 471-479.

77. Campbell DJ, Rong P, Kladis A, Rees B, Ganten D \& Skinner SL (1995). Angiotensin and bradykinin peptides in the TGR(mRen-2)27 rat. Hypertension, 25: 1014-1020.

78. Senanayake $P$, Moriguchi $A$, Kumagai $H$, Ganten D, Ferrario CM \& Brosnihan KB (1994). Increased expression of angiotensin peptides in the brain of transgenic hypertensive rats. Peptides, 15: 919-926.

79. Rocco S, Rebuffat P, Cimolato M, Opocher G, Peters J, Mazzocchi G, Ganten D, Mantero F \& Nussdorfer GG (1994). Zona glomerulosa of the adrenal gland in a transgenic strain of rat: a morphologic and functional study. Cell and Tissue Research, 278: 21-28.

80. Moriguchi A, Ferrario CM, Brosnihan KB, Ganten D \& Morris M (1994). Differential regulation of central vasopressin in transgenic rats harboring the mouse REN-2 gene. American Journal of Physiology, 267: R786-R791

81. Springate JE, Feld LG \& Ganten D (1994). Renal function in hypertensive rats for mouse renin gene. American Journal of Physiology, 266: F731-F737.

82. Tepel M, Theilmeier G, Bachmann J, Barenbrock M, Spieker C, Ganten D, Rahn KH \& Zidek W (1994). Increased cytosolic sodium and reduced $\mathrm{Na}$, K-ATPase activity in transgenic rat. Hypertension, 23: I-198I-202

83. Lemmer B, Mattes A, Böhm M \& Ganten D (1993). Circadian blood pressure variation in transgenic hypertensive rats. Hypertension, 22: 97-101.

84. Böhm M, Lee M, Kreutz R, Kim S, Schinke M, Djavidani B, Wagner J, Kaling M, Wienen W, Bader M \& Ganten D (1995). Angiotensin II receptor blockade in TGR(mREN2)27: Effects on renin-angiotensin-system gene expression and cardiovascular functions. Journal of Hypertension, 13: 891-899.

85. Djavidani B, Sander M, Kreutz R, Zeh K, Bader M, Mellon SH, Vecsei P, Peters J \& Ganten D (1995). Chronic dexamethasone treatment suppresses hypertension development in the transgenic rat TGR(mREN2)27. Journal of Hypertension, 13: 637-645.

86. Lee M, Böhm M, Kim S, Bachmann S, Bachmann J, Bader M \& Ganten D (1995). Differential gene expression of renin and angiotensinogen in the TGR(mREN-2)27 transgenic rat. Hypertension, 25: 570-580.

87. Lee MA, Böhm M, Paul M, Bader M Ganten U \& Ganten D (1996). Physiological characterization of the hypertensive transgenic rat TGR(mREN2)27. American Journal of Physiology, 270: E919-E929.

88. Zhao Y, Bader M, Kreutz R, FernandezAlfonso MS, Zimmermann F, Ganten U, Metzger R, Ganten D, Mullins JJ \& Peters $J$ (1993). Ontogenetic regulation of the mouse Ren-2d renin gene in transgenic hypertensive rats, TGR(mREN2)27. American Journal of Physiology, 265: E695-E707.

89. Peters J, Münter K, Bader M, Hackenthal E, Mullins JJ \& Ganten D (1993). Increased adrenal renin in transgenic hypertensive rats, TGR(mREN2)27, and its regulation by CAMP, angiotensin II, and calcium. Journal of Clinical Investigation, 91: 742-747.

90. Sander M, Bader M, Djavidani B, MaserGluth C, Vecsei P, Mullins J, Ganten D \& Peters J (1992). The role of the adrenal gland in the hypertensive transgenic rats TGR(mREN2)27. Endocrinology, 131: 807814.

91. Veniant M, Menard J, Bruneval P, Morley S, Gonzales MF \& Mullins J (1996). Vascular damage without hypertension in transgenic rats expressing prorenin exclusively in the liver. Journal of Clinical Investigation, 98: 1966-1970.

92. Sharp MG, Fettes D, Brooker G, Clark AF Peters J, Fleming S \& Mullins JJ (1996). Targeted inactivation of the Ren-2 gene in mice. Hypertension, 28: 1126-1131.

93. Bertaux F, Colledge WH, Smith SE, Evans M, Samani NJ \& Miller CC (1997). Normotensive blood pressure in mice with a disrupted renin Ren-1d gene. Transgenic Research, 6: 191-196.

94. Clark AF, Sharp MGF, Morley SD, Fleming S, Peters J \& Mullins JJ (1997). Renin-1 is essential for normal renal juxtaglomerular cell granulation and macula densa morphology. Journal of Biological Chemistry, 272: 18185-18190.

95. Tian X-L, Costerousse O, Urata H, Franz W-M \& Paul M (1996). A new transgenic rat model overexpressing human angiotensin-converting enzyme in the heart. Hypertension, 28: 520 (Abstract).

96. Langford KG, Shai S-Y, Howard TE, Kovac MJ, Overbeek PA \& Bernstein KE (1991). Transgenic mice demonstrate a testisspecific promoter for angiotensin-converting enzyme. Journal of Biological Chemistry, 266: 15559-15562.

97. Erickson RP, Kessler S, Kremling H \& Sen GC (1996). Species variation in the testicular 
angiotensin converting enzyme promoter studied in transgenic mice. Molecular Reproduction and Development, 44: 324331.

98. Zhou Y, Overbeek PA \& Bernstein KE (1996). Tissue specific expression of testis angiotensin converting enzyme is not determined by the -32 nonconsensus TATA motif. Biochemical and Biophysical Research Communications, 223: 4853.

99. Howard $T$, Balogh R, Overbeek $P$ \& Bernstein KE (1993). Sperm-specific expression of angiotensin-converting enzyme (ACE) is mediated by a 91-basepair promoter containing a CRE-like element. Molecular and Cellular Biology, 13: 18-27.

100. Krege JH, John SW, Langenbach LL, Hodgin JB, Hagaman JR, Bachman ES, Jennette JC, O'Brien DA \& Smithies O (1995). Male-female differences in fertility and blood pressure in ACE-deficient mice. Nature, 375: 146-148.

101. Carpenter $\mathrm{C}$, Honkanen AA, Mashimo $\mathrm{H}$, Goss KA, Huang P, Fishman MC, Asaad M, Dorso CR \& Cheung H (1996). Renal abnormalities in mutant mice. Nature, 380: 292

102. Esther CR, Marino EM, Howard TE, Machaud A, Corvol P, Capecchi MR \& Bernstein KE (1997). The critical role of tissue angiotensin-converting enzyme as revealed by gene targeting in mice. Journal of Clinical Investigation, 99: 23752385.

103. Hein L, Stevens ME, Barsh GS, Pratt RE, Kobilka BK \& Dzau VJ (1997). Overexpression of angiotensin AT1 receptor transgene in the mouse myocardium produces a lethal phenotype associated with myocyte hyperplasia and heart block. Proceedings of the National Academy of Sciences, USA, 94: 6391-6396.

104. Hoffmann $S$, Urata $H$, Krause $T$, Inagami T, Guo D-F, Paul M \& Ganten D (1994). Cardiac specific expression of human angiotensin II receptor type 1 in transgenic rats. International Symposium on Cellular and Molecular Aspects of Angiotensin Receptors, Gainesville, Florida, Abstract.

105. Masaki H, Matsubara $H$, Kurihara $H$, Inomata N, Nozawa Y, Mori Y, Murasawa S, Iwasaka T, Takahashi H \& Inada M (1997). Cardiac-specific overexpression of angiotensin AT2 receptor causes attenuated response to AT1 receptor-mediated chronotropic action. Hypertension, 30: 480 (Abstract)
106. Sugaya T, Nishimatsu S, Tanimoto $K$, Takimoto E, Yamagishi T, Imamura K, Goto S, Imaizumi K, Hisada Y, Otsuka A, Uchida H, Sugiura M, Fukuta K, Fukamizu A \& Murakami K (1995). Angiotensin II type 1a receptor-deficient mice with hypotension and hyperreninemia. Journal of Biological Chemistry, 270: 1871918722.

107. Matsusaka T, Nishimura $H$, Utsunomiya $H$, Kakuchi J, Niimura F, Inagami T, Fogo A \& Ichikawa I (1996). Chimeric mice carrying 'regional' targeted deletion of the angiotensin type 1a receptor gene. Evidence against the role for local angiotensin in the in vivo feedback regulation of renin synthesis in juxtaglomerular cells. Journal of Clinical Investigation, 98: 1867-1877.

108. Ito M, Oliverio MI, Mannon PJ, Best CF, Maeda N, Smithies O \& Coffman TM (1995). Regulation of blood pressure by the type $1 \mathrm{~A}$ angiotensin II receptor gene. Proceedings of the National Academy of Sciences, USA, 92: 3521-3525.

109. Chen X, Li W, Yoshida H, Tsuchida S, Nishimura H, Takemoto F, Okubo S, Fogo A, Matsusaka T \& Ichikawa I (1997). Targeting deletion of angiotensin type 1B receptor gene in the mouse. American Journal of Physiology, 272: F299-F304.

110. Ichiki T, Labosky PA, Shiota C, Okuyama $S$, Imagawa $Y$, Fogo A, Niimura $F$, Ichikawa I, Hogan BL \& Inagami T (1995). Effects on blood pressure and exploratory behaviour of mice lacking angiotensin II type-2 receptor. Nature, 377: 748-750.

111. Hein L, Barsh GS, Pratt RE, Dzau VJ \& Kobilka BK (1995). Behavioural and cardiovascular effects of disrupting the angiotensin II type-2 receptor in mice. Nature, 377: 744-747.

112. Forss-Petter $S$, Danielson PE, Catsicas $S$, Battenberg E, Price J, Nerenberg M \& Sutcliffe JG (1990). Transgenic mice expressing b-galactosidase in mature neurons under neuron-specific enolase promoter control. Neuron, 5: 187-197.

113. Gloster A, Wu W, Speelman A, Weiss S, Causing C, Pozniak C, Reynolds B, Chang E, Toma JG \& Miller FD (1994). The T alpha 1 alpha-tubulin promoter specifies gene expression as a function of neuronal growth and regeneration in transgenic mice. Journal of Neuroscience, 14: 7319-7330.

114. Zhuo L, Sun $B$, Zhang $C L$, Fine $A$, Chiu SY \& Messing A (1997). Live astrocytes visualized by green fluorescent protein in transgenic mice. Developmental Biology 187: 36-42

115. Brenner M, Kisseberth WC, Su Y, Besnard F \& Messing A (1994). GFAP promoter directs astrocyte-specific expression in transgenic mice. Journal of Neuroscience, 14: 1030-1037.

116. Hunter JJ, Tanaka N, Rockman HA, Ross Jr J \& Chien KR (1995). Ventricular expression of an MLC-2v-ras fusion gene induces cardiac hypertrophy and selective diastolic dysfunction in transgenic mice. Journal of Biological Chemistry, 270: 23173-23178.

117. Franz WM, Breves D, Klingel K, Brem G, Hofschneider PH \& Kandolf R (1993). Heart-specific targeting of firefly luciferase by the myosin light chain-2 promoter and developmental regulation in transgenic mice. Circulation Research, 73: 629-638

118. Lee K, Ross R, Rockman $H$, Harris $A$, O'Brien T, vanBilsen M, Shubeita $H$, Kandolf R, Brem G, Price J, Evans S, Zhu H, Franz W \& Chien K (1992). Myosin light chain-2 luciferase transgenic mice reveal distinct regulatory programs for cardiac and skeletal muscle-specific expression of a single contractile protein gene. Journal of Biological Chemistry, 267: 15875-15885.

119. Harats $D$, Kurihara $H$, Belloni $P$, Oakley $H$, Ziober A, Ackley D, Cain G, Kurihara Y, Lawn R \& Sigal E (1995). Targeting gene expression to the vascular wall in transgenic mice using the murine preproendothelin-1 promoter. Journal of Clinical Investigation, 95: 1335-1344.

120. Korhonen J, Lahtinen I, Halmekyto M, Alhonen L, Janne J, Dumont D \& Alitalo K (1995). Endothelial-specific gene expression directed by the tie gene promoter in vivo. Blood, 86: 1828-1835.

121. Li L, Miano JM, Mercer B \& Olson EN (1996). Expression of the SM22alpha promoter in transgenic mice provides evidence for distinct transcriptional regulatory programs in vascular and visceral smooth muscle cells. Journal of Cell Biology, 132: 849-859.

122. Yull FE, Wallace RM \& Clark AJ (1995). Restricted tissue-specific but correct developmental expression mediated by a short human alpha 1AT promoter fragment in transgenic mice. Transgenic Research, 4: 70-74.

123. Pinkert CA, Ornitz DM, Brinster RL \& Palmiter RD (1987). An albumin enhancer 
located $10 \mathrm{~kb}$ upstream functions along with its promoter to direct efficient, liverspecific expression in transgenic mice. Genes and Development, 1: 268-276.

124. Morley SD, Viard I, Parker KL \& Mullins JJ (1996). Adrenocortical-specific transgene expression directed by steroid hydroxylase gene promoters. Endocrine
Research, 22: 631-639.

125. Mellon SH, Miller WL, Bair SR, Moore CC, Vigne JL \& Weiner RI (1994). Steroidogenic adrenocortical cell lines produced by genetically targeted tumorigenesis in transgenic mice. Molecular Endocrinology, 8: 97-108.

126. Ding Y, Davisson RL, Hardy DO, Zhu L-J,
Merrill DC, Catterall JF \& Sigmund CD (1997). Inducible hypertension due to selective activation of an intrinsic intra-renal renin-angiotensin system in transgenic mice. Hypertension, 30: 480 (Abstract). 